\title{
Self-Perception on the Institutionalized Elderly Need of Dental Prosthesis
}

\author{
Arlete Maria Gomes Oliveira1 ${ }^{1}$, Joana Danielle Brandão Carneiro²@ ${ }^{\circledR}$, Glaucia Maria Bovi \\ Ambrosano ${ }^{1}$, Marcelo de Castro Meneghim ${ }^{1(0)}$
}

${ }^{1}$ Department of Community Dentistry, Piracicaba Dental School, University of Campinas, Piracicaba, SP, Brazil.

${ }^{2}$ Department of Policy, Management and Health, Public Health School, University of São Paulo, São Paulo, SP, Brazil.

Author to whom correspondence should be addressed: Arlete Maria Gomes Oliveira, Department of Community Dentistry, Piracicaba Dental School, University of Campinas, Av. Limeira, 901, Piracicaba, SP, Brazil. 13414-903. Phone: +55 19971011209. E-mail: arlete.maria@yahoo.com.br.

Academic Editors: Alessandro Leite Cavalcanti and Wilton Wilney Nascimento Padilha

Received: 19 September 2019 / Accepted: 24 April 2020 / Published: 04 June 2020

How to cite this article: Oliveira AMG, Carneiro JDB, Ambrosano GMB, Meneghim MC. Self-perception on the institutionalized elderly need of dental prosthesis. Pesqui Bras Odontopediatria Clín Integr. 2020; $20: e 4146$. https://doi.org/10.1590/pboci.2020.098

\begin{abstract}
Objective: To make an association between self-perception and the implementation of sociodemographic variables for the autonomous and / or partially dependent individuals in nursing homes. Material and Methods: Epidemiological, observational and cross-sectional study. The sample consisted of 208 institutionalized elderly, both sexes, 60 years old or older, independent or partially dependent, randomly selected from two long-term residential institutions. Subjective evaluation: self-perception questionnaire, Geriatric Oral Health Assessment Index, quality of life assessment, Oral Impacts on Daily Performance (OIDP), oral health self-assessment $(\mathrm{OH})$ and the need for dental prostheses. Bivariate analysis, chi-square test and multiple logistic regression were used, with the variables with $\mathrm{p}<0.05$ remaining in the model. Results: Men were edentulous (53.43\%), 68.75\% used some type of denture, and $64.91 \%$ required dental prostheses, $60.58 \%$ self-assessed $(\mathrm{OH})$ as good / excellent; who reported a need for dental prostheses presented 6.7 times (95\% CI: 3.2-14.3) and more likely to have an impact on OIDP, those who needed prosthetics had a 2.8 times chance $(95 \% \mathrm{CI}: 1.3-6.1)(\mathrm{p}<0.0001)$. The self-reported need for prostheses was associated with prevalence severity of impacts on QoL, eating, pronounce words correctly, Smile without feeling embarrassed; and the main reasons for not having badly adjusted teeth / dentures. Conclusion: The institutionalized elderly self-perceive the need for dental prostheses, but it does not have a negative impact on quality of life.
\end{abstract}

Keywords: Aged; Health Services for the Aged; Self Concept; Quality of Life; Oral Health. 


\section{Introduction}

The interest in aging has repercussions over the last few decades and the process of change in the behavior of elders has increased worldwide and presents the health sector with a challenge [1]. The projection of population growth has pointed out that in 2060, elders in Brazil may represent $26.7 \%$ of the total population $[2]$.

The aging process is characterized as the interaction between biological, psychic and social factors, and changes in the structure and physiology of systems [3]. Society is hardly prepared to face population aging by revealing the health system's difficulties in bearing the costs, accumulation of chronic pathologies, financial feasibility of social security, little social support for older people, and dubious quality of life [4,5].

In Brazil, the demographic transition has left gaps in the social conditions and health care of the population, which involve unpleasant experiences in coping with the physiological changes elderly people undergo at this stage of life $[6,7]$. Quite frequently, the families have an insufficient structure to provide care for the elders and are unable to keep them in their family environment. This has increased the demand for long-term residence institutions for elders (LTRI), pointed out as the solution for caring for elders outside of their family life [8].

The concept of quality of life must be considered from the individual perspective, as it develops in a manner that is inseparable from the conditions of life, such as health, accommodation, education, leisure, transport, self-esteem, based on functional capacity, socioeconomic level and satisfaction [3].

The factors associated with the oral condition and quality of life go beyond discomfort and pain and are also reflects in psychological and social aspects, such as personal appearance, communication and interaction $[1,9]$.

Data from the latest nationally based epidemiological surveys [10,11] have shown critical results for the oral conditions of the older population, with a high DMFT index (close to 28) and high rate of edentulism, a factor probably related to the type of dental care received throughout the course of life [6].

Self-perception of oral health reflects the subjective experience of individuals about their functional, social and psychological well-being, understanding and accepting their state of healths [12, 13]. Analysis of oral health needs by using tools for the evaluation of behavior and quality of life has been relevant in the planning of health actions for the older population $[1,14]$ in order to provide these elders with full care, with emphasis on health promotion and prevention of diseases, making it possible to revert the picture of unfavorable sociocultural conditions to achieve an old age with a better quality of life [15].

The hypothesis tested is that the elderly population in asylums presents a worse oral health condition, represented mainly by the absence of teeth, mediated by self-esteem problems, which end up affecting the selfperception of the need for prosthesis use. Given the above, the objective of this study was to analyze the association between the self-perception of the need for prosthesis use and sociodemographic variables for independent and / or partially dependent elderly people who live in nursing homes.

\section{Material and Methods}

\section{Study Design}

The research was a cross-sectional, analytical, observational epidemiological study. The study was developed in the city of Piracicaba, São Paulo, Brazil.

Sampling 
The study was developed in Long-Term Residence Institutions (LTRI) for older people. The minimum size of 208 individuals was calculated based on an alpha error of $5 \%$, power of $80 \%$, level of confidence of $95 \%$ and an effect size of 2 . People aged 60 years or older of both sexes were considered and classified according to their functional capacity as being independent or partially dependent, tested using the KATZ [18] Index.

The participants were randomly selected in two LTRI for older people situated in Piracicaba, Brazil. Excluded from the study were older people who presented with an unfavorable clinical health condition, without cognitive capacity to answer to the questionnaires evaluated in accordance with information on the clinical record charts (mental health with low cognitive deficits, senile dementia, Alzheimer's); those who for some temporary health reason could not be submitted to the oral clinical exam; and those who were totally dependent. After sample selection, the questionnaires were applied, followed by clinical evaluation to analyze the use and need of dental prostheses.

\section{Data Collection}

As research instruments, social and clinical indicators were used, described as follows: The criterion used to measure the self-perceived need for a prosthesis reported by the participant was through the question "Do you need a prosthesis?" included in the socioeconomic questionnaire as an individual clinical variable.

Sociodemographic and sociocultural Questionnaire: the questionnaire aimed to describe the characteristics of the target population and analyze the sociodemographic variables of the individuals researched, made up of questions referring to age, sex, marital status, educational level.

Oral health self-evaluation Questionnaire [19]: Questions that captured the best or worst oral health evaluation by the interviewee. The questionnaire was composed of three questions about the individuals' oral health, teeth and gums, with the option of four responses: poor, regular, good and excellent, to the first question. There were coded by means of values from zero to four, with the value zero corresponding to the worst perception of oral health and the value 4, to the best perception of oral health.

Oral health self-perception Questionnaire - GOHAI (The Geriatric Oral Health Assessment Index), an instrument for measuring the oral health of geriatric patients [20]. The index for determining geriatric oral health was made up of twelve questions that evaluated the older person's perception of oral problems that affected their physical and functional functions, psychological aspect such as pain and discomfort, questions relative to the frequency with which the interviewee experienced certain situations in the three months prior to the interview. For each of the questions the participants had 3 response options, which received values from 1 to 3 points, with reference to: "always" = 1; "sometimes" = 2; "never $=3$. The individual mean value of the total number of points obtained could vary from 12 to 36 , and the highest score meant a better evaluation of the individual's own oral health. The sum of scores of all the questions would determine the oral health evaluation index. The general score was classified into high perception (34-36 points), moderate (30 to 33 points) and low perception (<30 points)

The criterion for the use of dental prosthesis was based on the presence of complete dental prostheses and partial removable dental prostheses; whereas for the need of dental prostheses, the criterion used was based on the presence of existent prosthetic spaces; future prosthetic spaces left after having the indicated tooth extractions performed; and on the need of replacement of worn or damaged dental prostheses. The use and need of dental prostheses for the maxillary and mandibular arches was checked, by adopting criteria used previously [23], adapted to this study. 
The evaluations were made individually during six months in a space reserved within the institutions that participated in the study in order to facilitate dialog without inhibition, embarrassment or interference in the responses provided. A field diary was used to make notes about the perception of older people regarding their oral health. The field research was developed by a single researcher who received previous training before collecting the data. Training took place in 16 hours. The mean of the Kappa value was 0.90 For the clinical exam, wooden spatulas were used under natural light, in the older person's space in compliance with the criteria of adequate asepsis and biosafety regulations.

\section{Data Analysis}

The associations between self-perceived need for prosthesis use (outcome variable) and the other sociodemographic variables were analyzed using logistic regression models. For this, simple logistic regression models were constructed, estimating the gross odds ratios with the respective $95 \%$ confidence intervals. The variables with $\mathrm{p}<0.20$ in simple analyzes were tested in multiple logistic regression models, estimating adjusted odds ratios with the respective 95\% confidence intervals. The analyzes were performed in the $\mathrm{R}$ program (R Foundation for Statistical Computing, Vienna, Austria), adopting a significance level of $5 \%$.

Ethical Aspects

This research was approved by the Research Ethics Committee of the Piracicaba Dental School (CAEE 0127.0.167.000.11).

\section{Results}

The mean age of participants was 72.9 years, $52.8 \%$ were male and $81.7 \%$ were single (widows, divorced, separated, others). In relation to income, $91.3 \%$ of the participants reported having income from pensions or pensions, with values varying from 1 to 1.5 minimum wages. Regarding the educational level, $72.1 \%$ had a low educational level. In the self-assessment of oral health, $60.58 \%$ of the participants reported good or excellent oral health status. For GOHAI (57.21\%) the participants reported a moderate perception of the problems that affected their functions.

Table 1 shows the results of the associations among sociodemographic variables and the dependent variable "self-declared need of denture", dichotomized into "yes" and "no". The independent variables of the clinical and subjective criteria that were associated were the need of dentures evaluated by the professional $(\mathrm{p}=0.0030)(\mathrm{IC} 95 \%=0.2147-0.7110)$, edentulism $(\mathrm{p}=0.0389)(\mathrm{IC} 95 \%=1.0685-3.2211)$, self-evaluation of oral health $(\mathrm{p}=0.0024)(\mathrm{IC} 95 \%=0.2265-0.7087)$, quality of life $(\mathrm{p}<0.0001)(\mathrm{IC} 95 \%=3.5967-15.6411)$ and religion $(\mathrm{p}<0.0001)(\mathrm{IC} 95 \%=3.5-7.5)$.

The variables, gender, age, self-perception of health, income, educational level, use of dentures and marital status were not associated with the older people's declaration of their need of dental prostheses. Observed that the older people who declared they were Catholics, showed 4.9 times (IC95\%=3.2 -7.5 $\mathrm{p}<0.0001)$ more chance of self-perceiving their prosthetic rehabilitation needs, just as those who were edentulous had almost two times more chance $(1.85$, IC95\%=1.06 -3.22, p=0.03) of self-declaring their need of prosthetic rehabilitation.

In the multiple regression analysis, the observed that for self-declaration of the need of dentures, the variables that were significantly associated were the need of dentures $(p=0.02)$ and quality of life $(p<0.0001)$. The authors verified that the older people who needed some type of dental prosthesis had a low quality of life (Table 2 ). 
Table 1. Association between clinical and sociodemographic variables and perception self-declared by the need for a prosthesis reported by the individual.

\begin{tabular}{|c|c|c|c|c|c|}
\hline \multirow[b]{2}{*}{ Variables } & \multicolumn{4}{|c|}{ Self-Declared Need of Prosthesis } & \multirow[b]{2}{*}{ p-value } \\
\hline & $\begin{array}{c}\text { No } \\
\mathrm{N}(\%) \\
\end{array}$ & $\begin{array}{c}\text { Yes } \\
\text { N (\%) }\end{array}$ & OR & IC $95 \%$ & \\
\hline \multicolumn{6}{|l|}{ Need Denture } \\
\hline Yes & $62(45.9)$ & $73(54.1)$ & Ref. & & \\
\hline No & $50(68.5)$ & $23(31.5)$ & 0.39 & $0.21-0.71$ & 0.0030 \\
\hline \multicolumn{6}{|l|}{ Wear Denture } \\
\hline Yes & $78(54.6)$ & $65(45.4)$ & 0.91 & $0.50-1.64$ & 0.8807 \\
\hline No & $34(52.4)$ & $31(47.6)$ & Ref. & & \\
\hline \multicolumn{6}{|l|}{ Edentulism } \\
\hline Yes & $65(61.4)$ & $41(38.6)$ & Ref. & & \\
\hline No & $47(46.0)$ & $55(54.0)$ & 1.85 & $1.06-3.22$ & 0.0389 \\
\hline \multicolumn{6}{|l|}{ Age (Median) } \\
\hline $60-72$ & $49(47.1)$ & $55(52.9)$ & Ref. & & \\
\hline$\geq 73$ & $63(60.6)$ & $41(39.4)$ & 0.57 & $0.33-1.00$ & 0.0706 \\
\hline \multicolumn{6}{|l|}{ Sex } \\
\hline Male & $61(55.6)$ & $49(44.4)$ & 0.87 & $0.50-1.50$ & 0.7236 \\
\hline Female & $51(52.1)$ & $47(47.9)$ & Ref. & & \\
\hline \multicolumn{6}{|l|}{ Marital Status } \\
\hline Married & $19(50.0)$ & $19(50.0)$ & Ref. & & \\
\hline Unmarried & $93(54.8)$ & $77(45.2)$ & 0.82 & $0.40-1.67$ & 0.7293 \\
\hline \multicolumn{6}{|l|}{ Educational Level } \\
\hline Low Educational Level & $84(56.0)$ & $66(44.0)$ & Ref. & & \\
\hline Medium or Higher & $28(48.3)$ & $30(51.7)$ & 0.73 & $0.39-1.34$ & 0.3970 \\
\hline \multicolumn{6}{|l|}{ OH Self Valuation } \\
\hline Good/Excellent & $79(62.7)$ & $47(37.3)$ & 0.40 & $0.22-0.70$ & 0.0024 \\
\hline Poor/Regular & $33(40.3)$ & $49(59.7)$ & Ref. & & \\
\hline \multicolumn{6}{|l|}{ GOHAI } \\
\hline Low $<30$ & $77(52.1)$ & $71(47.9)$ & Ref. & & \\
\hline Moderate-High>30 & $35(88.4)$ & $25(41.6)$ & 0.77 & $0.42-1.42$ & 0.5009 \\
\hline \multicolumn{6}{|l|}{ OIDP } \\
\hline OIDP $>0$ & $101(64.8)$ & $55(35.2)$ & 0.14 & $0.06-0.30$ & $<0.0001$ \\
\hline $\mathrm{OIDP}=0$ & $11(21.2)$ & $41(78.8)$ & Ref. & & \\
\hline
\end{tabular}

Table 2. Multiple Logistic regression for self-declared perception by the individual about need for wearing dental prostheses.

\begin{tabular}{cccccc}
\hline Variables & \multicolumn{2}{c}{ Self-Declared Need of Dental Prosthesis } & & & OR \\
& No & Yes & IC 95\% & p-value \\
& N (\%) & & & & \\
\hline $\begin{array}{c}\text { Need Denture } \\
\text { Yes }\end{array}$ & $62(45.1)$ & $73(54.0)$ & Ref & & 0.0254 \\
No & $50(68.5)$ & $23(31.5)$ & 0.48 & $0.26-0.91$ & $<0.0001$ \\
$\begin{array}{c}\text { Quality of Life } \\
\text { OIDP }>0\end{array}$ & $101(64.7)$ & $55(35.3)$ & 0.16 & $0.08-0.35$ & \\
OIDP $=0$ & $11(21.2)$ & $41(78.8)$ & Ref. & & \\
\hline
\end{tabular}

*The level "Yes" of self-declared need of denture was considered a reference.

\section{Discussion}

The critical oral health context of the elderly population in Brazil refers to the curative and hospitalcentered character of the last decades, still with repercussions in the present day, despite a relative improvement, as evidenced by recent surveys of the Brazilian oral health condition [15,16,24,25]. 
Long-term institutions in Brazil have often been the solution for the housing of the elderly without family support, mainly, that due to economic and / or psychological insufficiency often fail to care for their elderly, increasing demand in these institutions, which in many cases aggregate elderly people from different social classes. In this study, we observed a worsening of the situation concerning the need and use of prostheses in the elderly, which allows us to highlight the importance of expanding the offer of specialized services for prosthetic rehabilitation in the Brazilian public health system. A framework of weakness in oral health in any life cycle causes impacts on the quality of life [26]. In this research, the elderly present similar characteristics regarding socioeconomic and clinical variables.

Quality of life is a subjective assessment of the individual, being marked by his position in the context of the culture and value system in which he lives and in relation to his goals, expectations and concerns [27]. This type of approach has been carried out for different life cycles [28,29,30]. Especially in the elderly population, how the individual evaluates himself and perceives his or her oral health is essential, since this understanding makes possible the direction of actions of health promotion and rehabilitation, being necessary for the planning of health services. Previous authors mentioned that the evaluation of the persons are different from the evaluations of the Dental Surgeons [31]; a similar result found in this research which reinforces the importance of the use of subjective instruments in health assessments, by favoring a greater knowledge of the history of the individual, planning of the oral treatment of elderly patients.

Self-perception (GOHAI) showed satisfaction, similar to those in the literature [32,33], with dissatisfaction being related to some symptomatological process. Although there is a clear divergence between oral health status and self-perception, the elderly reported the importance of having dental remnants considering that the preservation of the dental element is very important for self-esteem and image, regardless of quantity, reporting an almost emotional value for these elements, information is apprehended by the researcher during the interviews. When considering the individualized results of the domains of the OIDP Index for quality of life, this pointed as the main impact on quality of life associated with oral health the lack of teeth. The high rate of tooth loss found in the results of the present study has impacted on different domains of the OIDP index, including eating, speaking or pronouncing the words clearly and smiling without being ashamed, which are the ones that have the greatest impact.

When evaluating the impact of social, cultural, environmental and economic variables, which are likely to participate in a greater or lesser extent of the aging process, they were not statistically significant, unlike other studies [33,34], where there is a significant difference between men and women, and this is attributed to differences in perception and value given to oral health between the sexes. Other studies have shown that low level of schooling and income influence the self-perception of oral health and the impact of oral health on quality of life [29,35].

It was observed that the elderly with high socioeconomic status had a greater self-perception of their health, obtaining the highest GOHAI scores [20], differently, in this study, when the GOHAI scores were evaluated, there was no statistical significance, inferring that the population of institutionalized elderly, factors such as income and schooling, may not have large variations to be detected.

This negative picture of the oral health of the elderly, refer to the important role of the dental surgeon in the early loss of teeth since, in many cases, the decision by the exodontia was influenced by the professional [33]. The reduction in the prevalence of the most prevalent oral diseases among the younger individuals observed in the national surveys, together with the greater offer of public oral health services and the practice more directed to health promotion, allow us to design a different framework for the future in what the use and need of a prosthesis in the elderly, presenting a more positive picture [36]. 
Studies with institutionalized older people present various limitations (chronic co-morbidities, use of polypharmacy, among others) and the type of cross-sectional study, which presents a limitation in the interpretation of causality. Another limitation to be considered is referring to the clinical assessment instrument, which only observed need and use in a particular way, not considering prosthetic conditions or reasons for dental loss.

\section{Conclusion}

The institutionalized elderly people perceived the need for dental prosthesis, but did not impact the quality of life.

\section{Authors' Contributions}

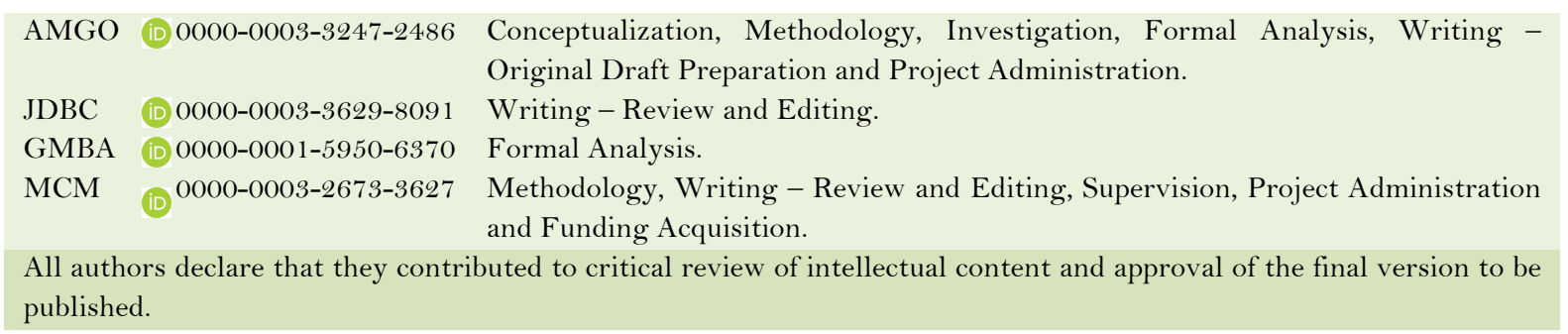

\section{Financial Support}

Coordenação de Aperfeiçoamento de Pessoal de Nível Superior - Brasil (CAPES) - Finance Code 001.

\section{Conflict of Interest}

The authors declare no conflicts of interest.

\section{References}

[1] Machado FCA, Costa APS, Pontes ALB, Lima KC, Ferreira MÂF. Daily difficulties associated with full conventional dentures. Ciên Saúde Coletiva 2013; 18(10):3091-3100. https://doi.org/10.1590/S1413-81232013001000034

[2] Instituto Brasileiro de Geografia e Estatistica. Diretoria de Pesquisas, Coordenação de trabalho e Rendimento. Pesquisa Nacional por Amostra de Domicílio 2011-2012. Brasilia: IBGE; 2012.

[3] Faller JW, Melo WA, Versa GLGS, Marcon SS. Quality of life for elderly registered in the family health strategy (fhs) of Foz do Iguaçu-PR. Esc Anna Nery 2010; 14(4):803-10. https://doi.org/10.1590/S1414-8145201000040002 1

[4] Manso EG, Galera PB. Profile of an elderly group participating in a program for chronic diseases prevention. Estud Interdiscip Envelhec 2015; 20(1):57-71.

[5] Porter J, Ntouva A, Read A, Murdoch M, Ola D, Tsakos G. The impact of oral health on the quality of life of nursing home residents. Health Qual Life Outcomes 2015; 13:102. https://doi.org/10.1186/s12955-015-0300-y

[6] Vettore MV, Marques RA, Peres MA. Social inequalities and periodontal disease: multilevel approach in SBBrasil 2010 survey. Rev Saúde Pública 2013; 47:29-39. https://doi.org/10.1590/So034-8910.2013047004422

[7] Miranda GMD, Mendes ACG, Silva ALA. Population aging in Brazil: current and future social challenges and consequences. Rev Bras Geriatr Gerontol 2016; 19(3):507-19. https://doi.org/10.1590/1809-98232016019.150140

[8] Camarano AA, Kanso S. As instituições de longa permanência para idosos no Brasil. Rev Bras Estud Popul 2010; 27(1):232-5. [In Portuguese]

[9] Kurihara E, Neves VJ, Kitayama VS, Endo MS, Terada RSS, Marcondes FK. Relationship between oral health and psychological factors in institutionalized and non-institutionalized elderly individuals. RGO 2013; 61(2):55-7.

[10] Brasil. Ministério da Saúde. Coordenação Nacional de Saúde Bucal. Condições de Saúde Bucal da População Brasileira. Projeto SB Brasil 2003. Resultados Principais. Brasília: Ministério da Saúde; 2004. [In Portuguese]

[11] Brasil. Ministério da Saúde. Brasília (DF): SB Brasil 2010: Pesquisa Nacional de Saúde Bucal. Resultados Principais; 2011. Available from: http://bvsms.saude.gov.br/bvs/publicacoes/pesquisa_nacional_saude_bucal.pdf. [Accessed on March 18, 2019]. [In Portuguese] 
[12] Nico LS, Andrade SSC, Malta DC, Pucca Júnior GA, Peres MA. Self-reported oral health in the Brazilian adult population: results of the 2013 National Health Survey. Ciênc Saúde Coletiva 2016; 21(2):389-98. https://doi.org/10.1590/1413-81232015212.25942015

[13] Silva DD, Held RB, Torres SVS, Sousa MLR, Neri AL, Antunes JLF. Self-perceived oral health and associated factors among the elderly in Campinas, Southeastern Brazil, 2008-2009. Rev Saúde Pública 2011; 45(6):1145-53. https://doi.org/10.1590/S0034-89102011005000068

[14] Miotto MMB, Almeida CS, Barcelos LA. Impacto das condições bucais na qualidade de vida em servidores públicos municipais. Ciênc Saúde Coletiva 2014; 19(9): 3931-40. https://doi.org/10.1590/1413-81232014199.12912013

[15] Palma JM, Schliebe LRSO, Tonello AS, Queiroz RCS. Edentulism and self-perception in oral health in elderly people from a city in the northeast of BRAZIL. Rev Pesq Saúde 2015; 16(3):144-8.

[16] Eustaquio-Raga MV, Montiel-Company JM, Almerich-Silla JM. Factors associated with edentulousness in an elderly population in Valencia (Spain). Gac Sanit 2013; 27(2):123-7. https://doi.org/10.1016/j.gaceta.2012.02.009

[17] Ulinski KG, Do Nascimento MA, Lima AM, Benetti AR, Poli-Frederico RC, Fernandes KB, et al. Factors related to oral health-related quality of life of independent Brazilian elderly. Int J Dent 2013; 2013: 705047. https://doi.org/10.1155/2013/705047

[18] Katz S, Ford AB, Moskowitz RW, Jackson BA, Jaffe MW. Studies of illness in the aged the index of ADL: a standardized measure of biological and psychosocial function. JAMA 1963; 185:914-9. https://doi.org/10.1001/jama.1963.03060120024016

[19] Silva SR, Fernandez RC. Self-perception of oral health status by the elderly. Rev Saúde Pública 2001; 35(4):349-55. https://doi.org/10.1590/S0034-89102001000400003

[20] Atchison KA, Dolan TA. Development of the geriatric oral health assessment index. J Dent Educ 1990; 54(11):680-7.

[21] Adulyanon S, Sheiham A. Oral Impacts on Daily Performances. In: Slade GD. Measuring Oral Health and Quality of Life. Chapel Hill: University of North Carolina; 1997.

[22] Locker D. Measuring oral health: a conceptual framework. Community Dental Health 1988; 5(1):3-18.

[23] Colussi CF, Freitas SFT, Calvo MCM. Epidemiological profile of caries and the use and need of prostheses in the elderly population of Biguaçu, Santa Catarina, Brazil. Rev Bras Epidemiol 2004; 7(1):88-97. https://doi.org/10.1590/S1415-790X2004000100011

[24] São Paulo. Pesquisa Estadual de Saúde Bucal. Relatório Final, 2016. Available from: http://w2.fop.unicamp.br/sbsp2015/down/ebook_relatorio_SBSP_2015.pdf. [Accessed on March 18, 2019]. [In Portuguese]

[25] Menezes-Silva R, Oliveria DWD, Biscaro PCB, Orti NP, Sá-Pinto AC, Ramos-Jorge ML. Epidemiological survey in elderly people (II): oral health, anxiety, depression, stress, and drug utilization. Sci Med 2016; 26(1):219-80. https://doi.org/10.15448/1980-6108.2016.1.21980

[26] Peres SHCS,Theodoro DS, Ribeiro DA, Avila ED, Greghi GA, Silva RPR. Labor dentistry diseases and lesions in professional practice. Rev Fac Odontol Araçatuba 2006; 27(1):54-8.

[27] The WHOQOL Group. Development of the World Health Organization WHOQOL-BREF Quality of Life Assessment. Psychol Med 1998; 28:551-8.

[28] Alvarenga FAS, Henriques C, Takatsui F, Montandon AAD, Telarolli Júnior R, Monteiro ALCC, et. al. Oral health impact profile in the quality of life of patients over 50 years old of two public institutions of Araraquara city, SP, Brazil. Rev Odontol UNESP 2011; 40(3):118-24.

[29] Guerra MJC, Greco RM, Leite ICG, Ferreira EF, Paula MVQ. Impact of oral health conditions on the quality of life of workers. Ciênc Saúde Coletiva 2014; 19(12):4777-86. https://doi.org/10.1590/1413-812320141912.21352013

[30] Paredes SO, Leal Júnior OS, Paredes AO, Fernandes JMFA, Menezes VA. Saúde bucal e qualidade de vida. Rev Bras Promoç Saúde 2015; 28(2):266-73. https://doi.org/10.5020/18061230.2015 [In Portuguese]

[31] Benedetti TRB, Mello ALSF, Gonçalves LHT. Elderly people living in Florianópolis: self-perception of oral health conditions and use of dental services. Ciênc Saúde Coletiva 2007; 12(6):1683-90. https://doi.org/10.1590/S1413-81232007000600029

[32] Alberte JSP, Ruscalleda RMI, Guariento ME. Quality of life and variables to pathological aging. Rev Bras Clin Med $2015 ; 13(1): 32-9$.

[33] Hiramatsu DA, Tomita NE, Franco LJ. Tooth loss and the image of the dentist in a group of senior citizens. Ciênc Saúde Coletiva 2007; 12(4):1051-6. https://doi.org/10.1590/S1413-81232007000400026

[34] Emami E, De Souza RF, Kabawat M, Feine JS. The impact of edentulism on oral and general health. Int J Dent 2013; 2013:498305. https://doi.org/10.1155/2013/498305

[35] Oliveira AMG, Zanin L, Flório FM. Saúde bucal, qualidade de vida e desempenho de atividades em populações de assentamentos rurais. Rev Ciênc Ext 2016; 12(4):83-97. [In Portuguese]

[36] Azevedo JS, Azevedo MS, Oliveira LJC, Correa MB, Demarco FF. Needs for dental prostheses and their use in elderly Brazilians according to the National Oral Health Survey (SBBrazil 2010): prevalence rates and associated factors. Cad Saúde Pública 2017; 33(8):e00054016. https://doi.org/10.1590/0102-311X00054016 